\title{
Tourist Perceptions on Supporting Infrastructure Facilities and Climate- Based Visiting Time of Ngebel Lake, Ponorogo
}

\author{
Ardhila Ayu Prasetyowati ${ }^{1 *}$, Nuddin Harahab $^{2}$, Soemarno ${ }^{3}$ \\ ${ }^{1}$ Environmental Resource Management Graduate Program, University of Brawijaya, Malang, Indonesia \\ ${ }^{2}$ Faculty of Fisheries and Marine Sciences, University of Brawijaya, Malang, Indonesia \\ ${ }^{3}$ Faculty of Agriculture, University of Brawijaya, Malang, Indonesia
}

\begin{abstract}
This study aims to analyze the tourists' perception about the importance and satisfaction on the product of fisheries tourism, and to assess the visiting time of tourist based on climate conditions. The research was conducted in May to June 2013 in Ngebel Lake, Ponorogo. We used descriptive quantitative approach, with 45 respondents. Data collected from interview, questionnaire and observation. Analytical methods were used to determine the perception of tourists on the satisfaction and interest in fisheries tourism products, i.e. Importance Performance Analysis (IPA). We also used Tourism Climate Index (TCI) to determine the visiting time of tourist. The results show the value of satisfaction and tourist interest is low, therefore the improvement of several aspects become important. It is encompasses: a) the existence of parking area; b) the condition of Ngebel Lake; c) planning and management system, the condition of the local community; and d) activities of fish course restaurant and fish farming system of floating net cages. TCl value indicates ideal conditions for tourists traveled in Ngebel Lake is in November (convenience index value of 106), in December (97) and in April (94). This appropriate time to visit Ngebel Lake is expected to create a good impression for the tourists and enjoy the various fisheries activities in Ngebel Lake.
\end{abstract}

Keywords: Importance Performance Analysis, Ngebel Lake, Tourist Climate Index

\section{INTRODUCTION}

A form of national development is by establishing community development activities to gain a sense of satisfaction emotionally and physically [1], e.g. developing the tourism sector. Tourism is one of the crucial sector for community development. Such tourism development requires support and participation of various stakeholders, such as tourists, the government, surrounding community, or the private sector to achieve a better tourism development [2].

Tourism is a combination of human activities that performed either individually or in groups, either local or international. The tourist activity is carried out by using convenience, services and various supporting factors provided by the government or by using the services from community to meet the tourists' demand [3]. The success of tourism was determined by the capability to improve the welfare and prosperity of the community. It is an obligation and duty of tourism towards foreign exchange [4].

Correspondence address:

Ayu Ardhila Prasetyowati

Email : ardhilaayu_prasetyowati@yahoo.com

Address : Jl. MT Haryono No. 169, Malang 65145, Indonesia
A tourism area offers various attractions and beautiful panoramic landscapes with distinctive features and advantages. These conditions expected to satisfy the tourists, giving benefits of offered attractions and tourist could directly participate in developing the environmental conservation to form awareness to preserve ecofriendly tourism area.

Tourist attractions can basically attract and hold tourists for longer visit and gave satisfaction and comfort to tourist. The quality is assessed from the condition of facilities, services, accessibility, and marketing that support the tourism area [2]. The perception of tourism for destination development therefore important.

Analysis of visitor perception is focused more on the condition of the natural charm of Ngebel Lake tourism related to activities of fisheries sector. Soemarno [5] stated the ratings attribute of perception for travelers are offered region's uniqueness, comfort, safety, cleanness, hospitality of surrounding communities and transportation access.

Climatic conditions are strongly influence the perceptions of tourists' demand, due to recent global climate change. As research of Suwarno [6], climate affected the comfort of tourists. Hot 
temperature reduces the convenience of tourists, thus causing a decrease in tourists visit. It is also expressed by Trenberth et al. (1995) in Hidayati [7], climate change directly or indirectly affected by human activities that change the atmosphere over the long period. Climate change includes gradual changes in temperature, air pressure, wind, humidity and precipitation.

Therefore, we need to assess the perception of tourist on the importance and satisfaction with the supporting infrastructure of the fisheries tourism and determine appropriate visiting time to the tourism area of Ngebel Lake.

\section{MATERIALS AND METHODS Study Area}

Ngebel Lake is a natural resource in East Java, which is used as attractions for tourism. This lake is located in the on the slopes of Mount Wilis, with an area of 6.2 ha with elevation of $734 \mathrm{~m}$ asl, $38 \mathrm{~km}$ away of Ponorogo. Temperatures of the Lake area is $22-23^{\circ} \mathrm{C}$, approximately $1.5 \mathrm{~km}$ wide, has a depth of $24 \mathrm{~m}$, and surrounded by 5 $\mathrm{km}$ road.

Besides the beautiful and stunning scenery, it also has the potential fisheries tourism area, which established since the beginning of 2004 until now. The activities include fish farming with floating net cages (Keramba Jaring Apung - KJA) and fish course restaurant (Rumah Makan Ikan RMI). However, only some of it can survive in current less stable economic situation.

These conditions showed that the availability of natural resources have attracted many people, due to the benefits that meet their needs. Nevertheless, it is realized that human activities cause environmental problems. Recently, the level of human needs increasing and encourages people to exploit natural resources excessively, and lead to damage on natural resources and environment [1].

The existence of some offered fisheries tourism activities give positive and negative impact on the lake, the tourists and the local community. The positive impact is the growing interest of tourists to visit the lake to enjoy the fish dish of RMI and education on offered fisheries attraction in Ngebel Lake. It also opens jobs opportunity for surrounding community. Otherwise, the negative impact is a reduction in the area's sustainability.

\section{Methods}

We used descriptive quantitative methods on data analysis. We determined the respondent from visitors by Quoted Accidental Sampling. Zaenal (2006) in Mateka [8] stated that the sampling imposed randomly on individuals or visitor that accidentally encountered visit the Ngebel Lake (usually in a holiday/weekend). The number of respondents is determine by Linear Time Function $\left(T=t_{0}+t_{1} n\right)$, resulted 45 respondent. Data was collected using questionnaires, observation, interviews and document collection. According Ancok (1995) in Kundofir [9], qualitative data were collected by observation, in-depth interviews, and available information on previously documents.

This study used two data analysis. Perception of visitors on Ngebel Lake use Importance Performance Analysis (IPA), combined the value of satisfaction and interest in the form of a Likert scale on supporting fishery products offered in Ngebel Lake. Second, we used Tourism Climate Index (TCI) to determine the visiting time based on climatic conditions. Climatological data obtained from Class 1 Station of Iswahyudi airport during 2012.

IPA analysis also proposed previously by Santoso [10], stated that the IPA analysis is a tool commonly used in assessing the perception of tourists to the quality improvement of the products or services offered by a particular tourism area. It also explained by Ekayana et al. [1] that IPA analysis results are used as a proposal for the improvement of certain tourism areas. This method assessed the value of each variable of satisfaction and interest of tourism's attraction attribute. This value then inserted into the Cartesian diagram and it resulted the quadrant of first priority, maintain the achievement, low priority, and ignore. The diagram implied the tourist perception of satisfaction and interests on supporting facilities and infrastructure of fisheries tourism activities. IPA formula is described below.

Description:

$$
\bar{X}=\frac{\sum_{i=1}^{n} \mathrm{Xi}}{n} \quad \bar{Y}=\frac{\sum_{i=1}^{n} \mathrm{Yi}}{n}
$$

$\bar{X}=$ average level of satisfaction

$Y=$ average level of interests

$\mathrm{n}$ = number of respondents

Formula for the division in the Cartesian diagram:

$$
\overline{\bar{X}}=\frac{\sum_{i=1}^{n} \overline{X l}}{k} \quad \overline{\bar{Y}}=\frac{\sum_{i=1}^{n} \bar{Y} \bar{l}}{k}
$$


Description:

$\overline{\bar{X}}=$ average score of all attributes of tourist's satisfaction

$\overline{\bar{Y}}=$ average score of all attributes of tourist's interest

$\mathrm{k}=$ number of used tourist quality attributes

Analysis of $\mathrm{TCl}$ was previously advanced by Cengiz et al. [11] to determine the decision rate for visiting the tourism's sites. It is calculated by considering several variables including rainfall, light, humidity, air temperature and wind speed in the area of Ngebel Lake. $\mathrm{TCl}$ equation is showed below.

$$
\mathrm{TCI}=2[4 \mathrm{CID}+\mathrm{CIA}+2 \mathrm{R}+2 \mathrm{~S}+\mathrm{W}]
$$

Description:

$\mathrm{TCl}=$ tourism Climate Index

$\mathrm{CID}=$ daytime comfort index, include: average of max. air temperature $\left({ }^{\circ} \mathrm{C}\right) \&$ average of min. relative humidity (\%)

$\mathrm{CIA}=$ daily comfort index, include: average air temperature $\left({ }^{\circ} \mathrm{C}\right) \&$ average relative humidity $(\%)$

$=$ rainfall $(\mathrm{mm})$

$=$ daily duration of sun shine $(\mathrm{h})$

$=$ wind $\operatorname{speed}(\mathrm{m} / \mathrm{s})$

Hadi et al. [12] explained the necessary of humidity calculation in Thermal Humidity Index (THI) before calculating the $\mathrm{TCl}$ and comfort index. THI calculation need the variable of air temperature $(\mathrm{Ta})$, rainfall, humidity $(\mathrm{RH})$ and wind speed in the formula:

$$
\begin{aligned}
& \mathrm{THI}=0.8 \mathrm{Ta}+(\mathrm{RHxTa}) / 500 \\
& \mathrm{TCI}=2\{(4 \mathrm{xCID})+\mathrm{CIA}+(2 \mathrm{XP})+(2 \mathrm{xS})+\mathrm{W}\}
\end{aligned}
$$

\section{RESULTS AND DISCUSSION}

\section{Tourism in Ngebel Lake}

Lake Ngebel is a tourism site in Ponorogo, East Java - taken from the name of the Subdistrict, Ngebel - which established by the Government in 1984. Public transport are available from Jenangan Terminal, Ponorogo for 45 minutes, while from Madiun almost takes two hours without transit, directly via Mlilir or Dolopo Regency. Dolopo is well known for its low negotiable price of Durian because it is directly harvested from the local garden.

The nature tourism of Ngebel Lake emphasize on the beauty of the panorama. It is also supported by several attractions including water tourism, culinary, and various accessories shop and entertainment for tourists. Ngebel Lake waters also has crucial functions for fisheries which use the potential resource of the lake. Fisheries activities in Ngebel Lake including the floating net cages system for fishing, business of fish course restaurant (RMI) and conventional fishing. These activities was instrumental in decreasing the poverty by job creation and socioeconomic development for local community.

The area of Ngebel Lake also provides various tropical fruits such as durian, mangosteen, pundung, and etc. The Lake also has various fish; the most dominant is Hampala fish or Ngongok.

Main attraction of tourism in Ngebel Lake is a beautiful natural tourism area, with impressive panoramic views, and supported by cold temperatures, less noise, and easy road access. Ngebel Lake tourism offer quite affordable tourism. The community around the area prioritizes hospitality and polite manner in providing services to tourists.

\section{Importance Performance Analysis (IPA)}

We determine the priorities on management and development of facilities and infrastructure based on the perception of tourists, which will affect the tourists' decision to the tourism area of Ngebel Lake. This priorities assessment related to the value of satisfaction and interests on the available facilities and infrastructure in the tourism area of Ngebel Lake.

\section{Perception of Visitors}

Generally perception is the effort of a person to comprehend and understand the environmental conditions that involve an interpretation institution as a media to present information on a person's psychological experience. Perception of the tourists can be expressed as participatory statement on the visited tourism area with view of tourism attraction [4].

The assessment on the tourism area of Ngebel Lake was aimed to make the area into a prime fishery tourism attraction. Development priority was need for the consideration on improvement efforts. Some of variables that not optimally support the development of Ngebel Lake tourism to be fisheries tourism area in Ponorogo are:

a) Floating net cages in Ngebel Lake are not maintained well. This condition is implied in $44 \%$ of respondents concern more attention for floating net cages conditions in setting the system to be neat and maintained the sustainability of waters environment.

b) Some fish course restaurant along the edge of the lake is lack of awareness to the cleanness around the lake. It is seen that $26 \%$ of respondents expect RMI to pay 
attention to the level of cleanliness; an offered service to the tourists of Ngebel Lake.

c) Existing fishing areas have not been maintained well, in terms of safety, convenience, and supporting facilities for fishing, e.g. rental of fishing equipment, and fish feed shop. Total of $30 \%$ respondents expect the development of the fishery activity.

d) Crucial supporting infrastructure is location of parking areas. The setting of parking area is not conducive and disorganized, caused inconvenience to the visitors.

e) The road conditions to the tourism area of Ngebel Lake are still in improvement. Total of $50 \%$ respondent expect the development and improvement on roads for smooth access to Ngebel Lake.

f) The area managers are lack of attention on environmental conditions around the lake. The management should add more signs or warning for keeping the cleanness that placed on the edge of the lake to remind the visitors.

Description on the perception of tourists to the services and facilities of the infrastructure conditions showed that Ngebel Lake still require adequate attention from the government to improve the comfort and safety of the tourists. Additional activities for fisheries tourism attraction are as follows: areas for fishing activity, floating net cages plus fish feeding activities, educational tourism (edu-tourism) on fisheries for visitors - particularly children, and specialized markets site for fish catch from aquaculture of tilapia fish. Previous study of Handayawati [13] also explained that the condition of facilities in Ngebel Lake according to the tourist's perception is $31.94 \%$ respondent prefer water attraction than others.

\section{Level of Suitability}

The rate of suitability related to fisheries sector in Ngebel Lake was 57\% - 111\%. Level of suitability which $<100 \%$ were consisted of 20 variables. It indicated that the condition requires more attention for improving the performance of management system. The level of suitability which $>100 \%$ were two variables, indicated that the performance of management system needs to be maintained. The lowest level of suitability is the variable of cleanness in the lake area, while the highest level of suitability is the natural beauty of Ngebel Lake scenery (Table 1). Handayawati [13] research also indicated that the waste management in the Ngebel Lake needs improvement from both manager and tourists.

\section{Cartesian Diagram}

Average value of satisfaction towards 22 variables in Ngebel Lake were ranged from 2 to 4.8 , while average value of interest ranged from 2.7 to 4.6 (Table 2, Fig. 1). Quadrant A (Priority Quadrant/High Importance, Low Performance), seen from the tourists' interest, the product or service was on high level.

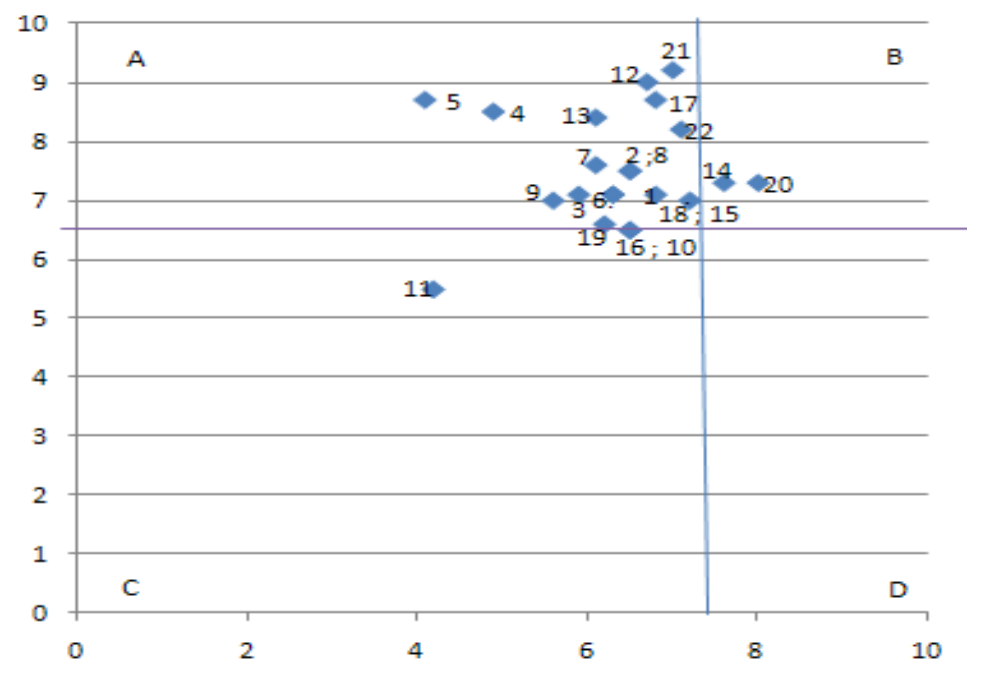

Figure 1. Quadrant of Infrastructure in Ngebel Lake 
However, tourist satisfaction scores showed that 19 variables still showed a low condition, thus need improvement as its main priority, variables of: 1) parking area; 2) safety of visitor's vehicle; 3) parking attend-ants; 4) lake's edge cleanness; 5) waste manage-ment; 6) impression and leisure during visits; 7) development of fisheries' objects; 8) manager of fisheries' tourism; 9) charges of visit; 10) promo-tion of fisheries' tourism; 12) public participation in service of mat rental, food and beverage; 13) cleanness of food/snacks stall; 15) food taste; 16) site convenience of $\mathrm{RMI}$; 17 ) service to the consumers; 18 ) cleanness of the RMI; 19) suitable price with the quality of service, taste and cleanness; 21) water sanitation in Ngebel Lake; 22) leisure to KJA activities in Ngebel Lake.

Quadrant B (Quadrant of continue the achievement/High Importance, High Performance), reviewed from tourist's interest, the product or service were on high level. However, reviewed from the tourist's satisfaction indicated that the two variables is in good condition and still need to be maintained and may be improved in the system management. The two variables are variable 14 (Level of community's ability in the services provision (Polite, Smile, and greetings)) and 20 (Beautiful scenery of Ngebel Lake).

Quadrant C (Quadrant of Low Priority/Low Importance, Low Performance) shows that variable 11 (Ease of obtaining information on products of fishery tourism) included in this quadrant, because visitors assume that only less benefits received by tourists in Ngebel Lake. Quadrant D (Quadrant of Excessive/Low Importance, High Performance) also suggests that visitors' assumed that the level of interest and satisfaction is balance, because there are no variables in the quadrant $D$.

Table 1. The Level of Suitability on Satisfaction and Interest of Fisheries in Ngebel Lake

\begin{tabular}{|c|c|c|c|c|c|}
\hline Symbol & Variable & $\frac{\text { Satisfaction }}{\mathrm{X}}$ & $\frac{\text { Interests }}{\mathrm{Y}}$ & $\begin{array}{l}\text { Level of } \\
\text { Suitability }\end{array}$ & $\begin{array}{l}\text { Necessary } \\
\text { Strategy }\end{array}$ \\
\hline $\mathbf{a}$ & b & c & d & $e=c / d(\%)$ & f \\
\hline & Parking & & & & \\
\hline I.1 & Parking area & 3,3 & 3,5 & 94 & improvement \\
\hline 1.2 & Safety of visitors' vehicle & 3,2 & 3,7 & 87 & improvement \\
\hline \multirow[t]{2}{*}{1.3} & Parking attendants & 2,9 & 3,5 & 83 & improvement \\
\hline & Ngebel Lake & & & & \\
\hline II.1 & Lake's edge cleanness & 2,4 & 4,2 & 57 & improvement \\
\hline 11.2 & Waste management & 2 & 3,4 & 59 & improvement \\
\hline \multirow[t]{2}{*}{11.3} & Impression and leisure during visits & 3,5 & 4,3 & 81 & improvement \\
\hline & Planning and Management & & & & \\
\hline III.1 & Development of fisheries' objects & 3 & 3,7 & 81 & improvement \\
\hline III.2 & Manager of fisheries' tourism & 3,2 & 3,6 & 89 & improvement \\
\hline III.3 & Charges of visit & 2,7 & 3,4 & 79 & improvement \\
\hline III.4 & Promotion of fisheries' tourism & 3 & 3,2 & 94 & improvement \\
\hline \multirow[t]{2}{*}{ III.5 } & $\begin{array}{l}\text { Ease of obtaining information on products of } \\
\text { fishery tourism }\end{array}$ & 2 & 2,7 & 74 & improvement \\
\hline & Local Communities & & & & \\
\hline IV.1 & $\begin{array}{l}\text { Public participation in service of mat rental, food } \\
\text { and beverage }\end{array}$ & 3,3 & 4,4 & 75 & improvement \\
\hline IV.2 & Cleanness of food/snacks stall & 3 & 4,1 & 73 & improvement \\
\hline \multirow[t]{2}{*}{ IV.3 } & $\begin{array}{l}\text { Level of community's ability in the services } \\
\text { provision (Polite, Smile, and greetings) }\end{array}$ & 3,7 & 3,6 & 103 & maintained \\
\hline & Culinary Activity & & & & \\
\hline V.1 & Food taste & 3,1 & 3,5 & 89 & improvement \\
\hline V.2 & Site convenience & 3 & 3,2 & 94 & improvement \\
\hline V.3 & Services to the customers & 3,3 & 4,2 & 79 & improvement \\
\hline V.4 & Cleanness & 3,1 & 3,5 & 89 & improvement \\
\hline \multirow[t]{2}{*}{ V.5 } & $\begin{array}{l}\text { Suitable price with the quality of service, taste and } \\
\text { cleanness }\end{array}$ & 3 & 3,2 & 94 & improvement \\
\hline & Keramba - floating net cage & & & & \\
\hline II.1 & Beautiful scenery of Ngebel Lake & 4 & 3,6 & 111 & maintained \\
\hline 11.2 & Water sanitation in Ngebel Lake & 3,4 & 4,5 & 76 & improvement \\
\hline 11.3 & Leisure & 3,5 & 4 & 88 & improvement \\
\hline
\end{tabular}




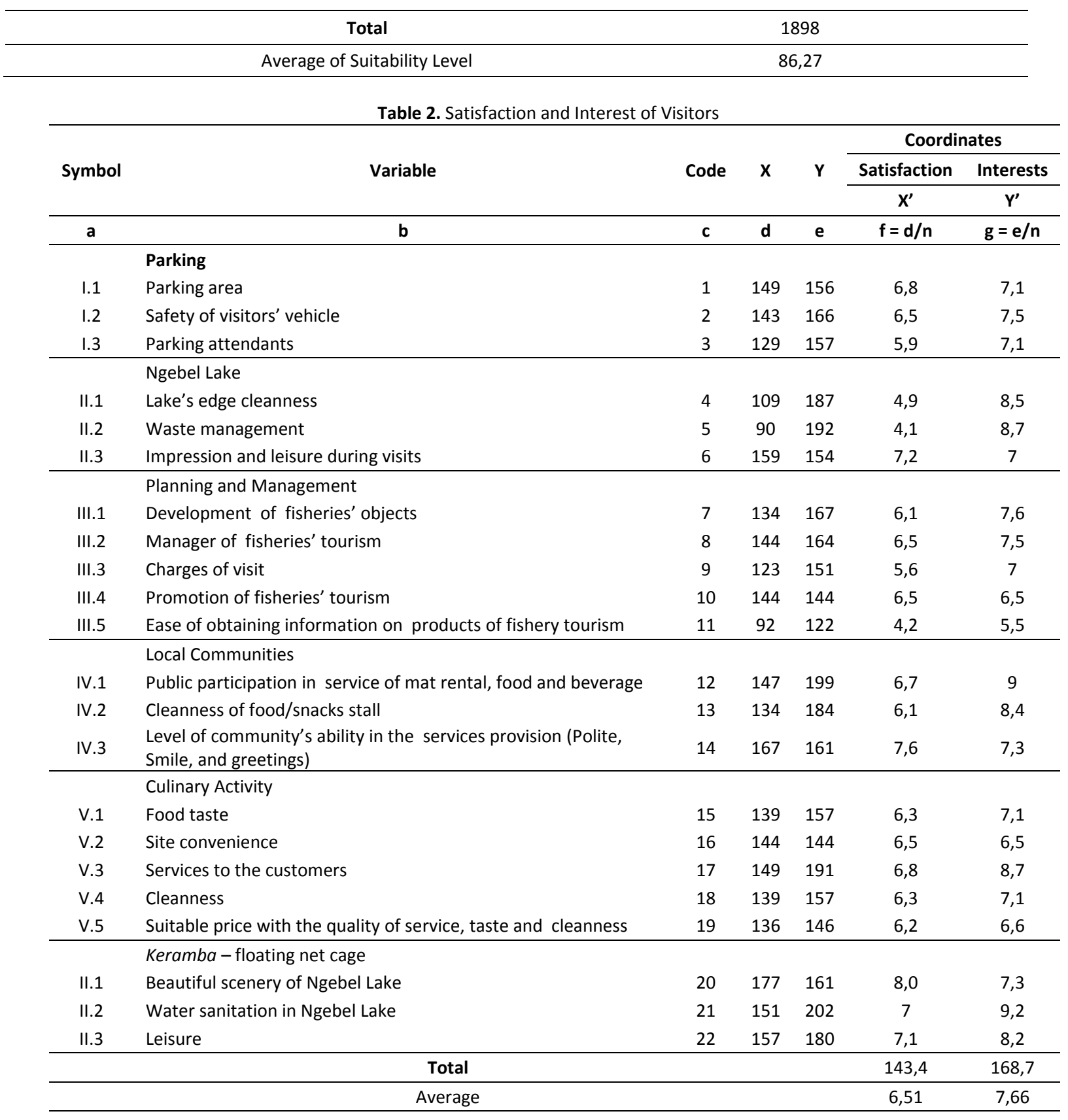

\section{Tourism Climate Index (TCI)}

Tourism climate index is a tool that used as a subjective analysis of the supporting data for perception of tourists to determine visiting time based on climate or weather conditions and tourist comfort index [11]. The variables included air temperature, humidity, rainfall, and wind speed.

Ngebel Lake included in the District of Ngebel located in altitude of $\pm 734 \mathrm{~m}$ asl. The average temperature per year is $27.4^{\circ} \mathrm{C}$, the highest temperature is in October, $29^{\circ} \mathrm{C}$ and the lowest temperature is in January of $25.7^{\circ} \mathrm{C}$. Average rainfall is $164.4 \mathrm{~mm}$ per year, with the highest levels of rainfall in December $533.7 \mathrm{~mm}$, and the lowest in July-September $0 \mathrm{~mm}$. Average wind speed per year is $417 \mathrm{~m} / \mathrm{s}$, with the largest wind speed in July $533 \mathrm{~m} / \mathrm{s}$ and the lowest in February at $287 \mathrm{~m} / \mathrm{s}$. Average humidity during the past year was $73.25 \%$, with the highest humidity level in January by $86 \%$ and the lowest in September by $59 \%$ (Fig. 2). 


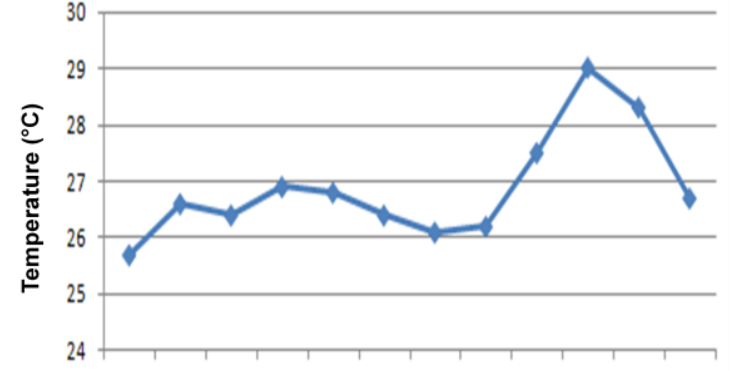

a Jan Feb Mar Apr May Jun Jul Aug Sep Oct Nov Des MONTHS

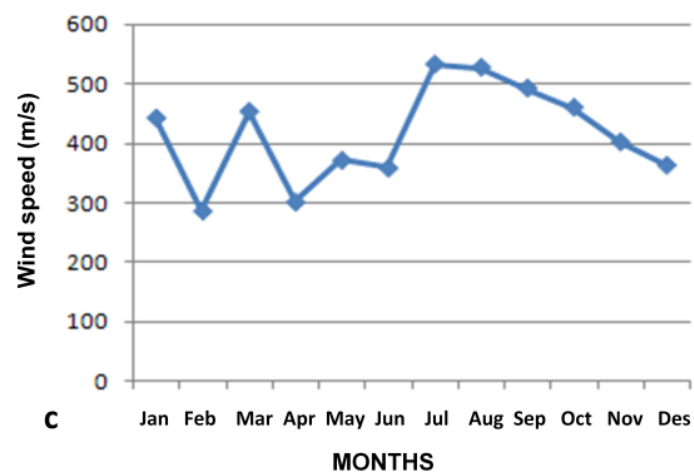

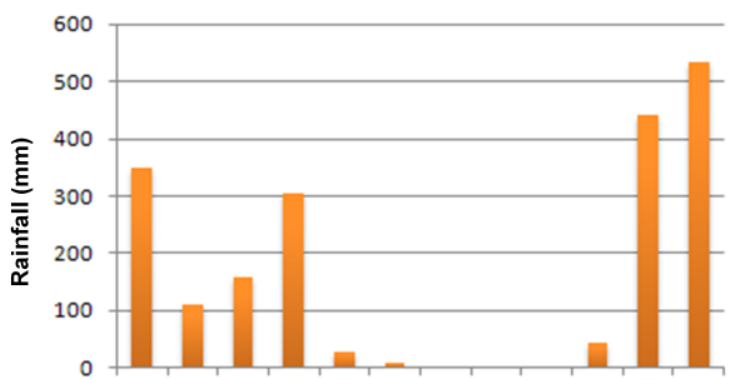

b Jan Feb Mar Apr May Jun Jul Aug Sep Oct Nov Des MONTHS

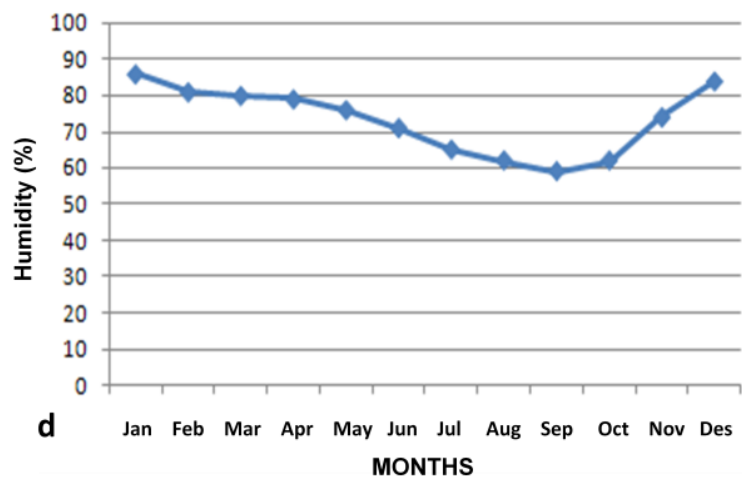

Figure 2. Climate and Weather Conditions of Ngebel Lake 2012: a) Temperature; b) rainfall; c) wind speed; d) thermal humidity

According to Diena [14], index of comfort, especially for Indonesian in tourism activities, are usually in THI range of 20-26. According to the calculation, the daily comfort index of $\mathrm{THI}$ for Ngebel Lake showed that January to December 2012 is favorable conditions for doing visitation, whenever they willing to. Otherwise, $\mathrm{TCl}$ values indicate the value of 106 in November, 97 in
December and 94 in April (Fig. 3), which includes as excellent conditions for tourism activities in Ngebel Lake area. This classification based on Mieczkowski [15] who explained that $\mathrm{TCl}$ of 100 said to be perfect, while 80 said to be very good, $60-79$ is considered good, $40-59$ is acceptable, and below 40 indicates poor condition for tourism activities.

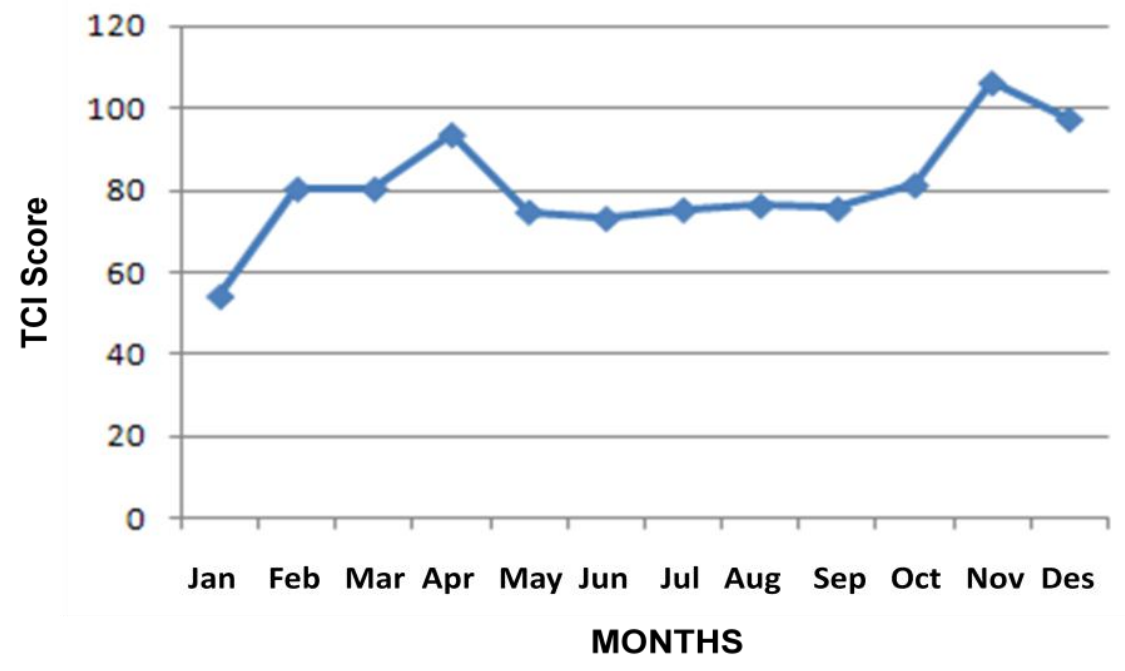

Figure 3. TCI Value of Ngebel Lake Tourism Area 2012 


\section{CONCLUSION}

Satisfaction and interest of tourists to the facilities and infrastructure of fisheries tourism in Ngebel Lake showed that 17 variables are included in good condition and still need to be maintained and possibly improved. Conversely, there are five very weak variables that show a low condition which needs an improvement, i.e. park attendants, lake's edge cleanness, waste management, charges of visit, and ease of obtaining information on products of fishery tourism. TCl value indicates that preferable times to visit Ngebel Lake tourism are in April, November and December. However, other months also showed good conditions for tourist visiting Ngebel Lake.

\section{Recommendations}

Ngebel Lake management requires further study to add important input on tourism activities. Ngebel Lake also require input and support from the local government to continue the fishery tourism activities, which will be used as a media of edu-tourism, and to maintain the sustainability of fishery household income. Good cooperation between the private stakeholder and government should be maintained to develop Ngebel Lake.

\section{REFERENCES}

[1] Ekayana, H., Antariksa, Soemarno. 2012. The development of nature tourism in Derawan Island. Graduate Program. University of Brawijaya. Malang.

[2] Marti, H.C. 2014. Tourists perception towards the development of Tourism Stem Dolphin Center. Accessed on April $5^{\text {th }} 2014$.

[3] Karyono, A.H. 1997. Tourism. Grasindo. Jakarta.

[4] Yoeti, O.K. 1997. Development of tourism planning. PT Karta Unipres. Jakarta.

[5] Soemarno. 2000. Basic planning of the development of the region and agriculturalbased community empowerment: models and methods. Faculty of Agriculture, University of Brawijaya. Malang.

[6] Suwarto, Titania. 2011. The influence of climate and its changes of Pangandaran Beach tourism destinations. The City and Territory Planning Journal, 22 (1).

[7] Hidayawati, R. 2001. The issue of climate change in Indonesia: a few example cases. Doctotal Program. Bogor Agricultural University.
[8] Mateka, J.A. 2013. The analysis of the demand of visitors towards attractions in Balekambang Beach Malang. Thesis. Faculty of Fisheries and Marine Sciences. University of Brawijaya. Malang.

[9] Kundofir. 2008. The behavior of the community in environmental management (studies on the estuary Waterfront City Boom Banyuwangi). Journal of The Fisheries Research, 11 (1).

[10] Santoso, S. 2006. Using SPSS and Excel to measure consumer attitudes and satisfaction. PT Elex Media Komputindo. Jakarta.

[11] Cengiz, T., Cengiz A., Vedat C., Abdullah K. 2008. Climate comfortable for tourism: A case study of Canakkale. Balwois. Republic of Macedonia.

[12] Hadi, R., Komang A.R., I Gusti A.G. 2012. Evaluation Index of Comfort City Park (Puputan Badung Field I Gusti Ngurah Made Agung) Denpasar, Bali. Agroeteknologi Tropics, 1 (1).

[13] Handayawati, H.S. 2011. Analysis of tourist satisfaction in Telaga Ngebel, Ponorogo. Graduate Program. University of Brawijaya. Malang.

[14] Diene, S. 2009. The influence of land use change and closing of suburban comfort in West Bogor. Thesis. Landscape Architecture Courses. Faculty of Agriculture. Bogor Agricultural University.

[15] Mieczkowski, Z. 1985. The Tourism Climate Index: a method for evaluating world climates for tourism. The Canadian Geographer, 29, 220-233. 